\title{
Varicella-Zoster Scar Treatments: A Tertiary Review
}

\author{
Arash Pour Mohammad ${ }^{1}$, Mohammadreza Ghassemi ${ }^{2^{*}}$ (D) \\ Received: 6 Jan 2021 \\ Published: 18 Oct 2021
}

\begin{abstract}
Chickenpox is a highly communicable disease caused by Varicella Zoster Virus. Varicella rash commonly evolves into permanent depressed scars, documented in up to $18 \%$ of post varicella patients, leaving life-long cosmetic issues for patients. Although there is a lot of reviews on depressed scars, the viral etiology and the unique scar morphology of post varicella scar discriminate it from other depressed scars. Therefore it is required to assess the efficacy of scar removal modalities on these scars, specifically. Yet, despite the prevalence, there is no comprehensive review on chickenpox scars' treatment, particularly.

This review provides an overview and categorization of efficacy and adverse events of various methodls used in the treatment of post varicella skin scars. A comprehensive literature search was performed on major databases, including all papers related to post varicella scar treatment until 2020 .

The results were categorized into topical treatment with tretinoin, systemic medical treatments with topiramate and isotretinoin, noninvasive procedures including chemical peelings, micro-needling and laser, invasive procedures including dermal grafting and subcision-suction method, and combination therapies.

According to literature, chemical peeling with trichloroacetic acid was the most frequently used method in the treatment of chickenpox scar, revealing moderate to excellent response in patients. However, there is insufficient evidence to accurately compare the efficacy of other modalities on these scars specifically.
\end{abstract}

Keywords: Varicella-Zoster, Chickenpox, Scar treatment, Atrophic Scar

Conflicts of Interest: None declared

Funding: None

\section{*This work has been published under CC BY-NC-SA 1.0 license.}

Copyright $₫$ Iran University of Medical Sciences

Cite this article as: Pour Mohammad A, Ghassemi M. Varicella-Zoster Scar Treatments: A Tertiary Review. Med J Islam Repub Iran. 2021 (18 Oct);35:136. https://doi.org/10.47176/mjiri.35.136

\section{Introduction}

Varicella-Zoster virus is responsible for Chickenpox, a common contagious disease of childhood. The peak incidence is between 5 and 9 years, and by the age of $14,91 \%$ of the population have already suffered this illness (1, $2)$. A common complication of it is the permanent depressed scars, documented in 7 to $18 \%$ of post varicella patients (3). The early evolution of scars in childhood and their persistence into adolescence, in addition to scars'

Corresponding author: Dr Mohammadreza Ghassemi, Ghassemi.mr@iums.ac.ir

1. Medical Student, Student Research Committee, Faculty of Medicine, Iran University of Medical Sciences, Tehran, Iran

2. Department of Dermatology, Rasoul Akram Hospital, Iran University of Medical Sciences, Tehran, Iran facial distribution of $40 \%$, make post varicella scar (PVS) patients susceptible to psychosocial consequences and functional impairments in school years (4).

Hence, chickenpox scar removal is a popular aesthetic demand in dermatology patients, and similar to other depressed scars, a variety of choices from medical treatments to lasers and surgical techniques are considered for its treatment (5). But despite its high prevalence and major

\section{$\uparrow$ What is "already known" in this topic:}

Varicella-zoster scar is characterized by its distinct depressed morphology. Despite its high prevalence and the impact on patients' cosmetic appearance, there is a paucity of information for its treatment methods.

\section{$\rightarrow$ What this article adds:}

This is the first exclusive review on post-varicella-zoster scar treatments. It includes all related publications since 1990, providing categorization of methods and modalities used in the treatment of chickenpox scar. 
impact on patients' quality of life, there is a paucity of information in the medical literature regarding different treatment methods of chickenpox scars (6).

The pathophysiology of depressed scars, their background etiology, and the level and extent of the cutaneous involvement are important factors for selecting the most suitable modality for their treatment (5). Many features of PVS are distinctive to other depressed scars specially acne scars, which could be attributed to epidermal layer involvement in primary varicella infection, whereas acne scar is formed in deeper layers and mainly involves the pilosebaceous units (7). In addition, acne scars are presented in different types (Icepick, boxcar, rolling, etc.) contrary to chickenpox scars which share a similar morphology $(8,9)$.

Herein is the first comprehensive review focusing on PVS treatment methods and modalities exclusively.

The objective of this review is to provide an overview and to categorize various modalities used in the treatment of PVS found in the published medical literature.

\section{Methods}

A comprehensive literature search was performed on various databases, including PubMed, Embase, Scopus, Web of Science, Ovid, and Cochrane library. The search strategy included all the papers from 1950/01/01 to 2020/06/01 regardless of their publication status, having the following major keywords: (Varicella OR Varicella Zoster OR Chickenpox) AND (Scar(s) OR Cicatrix) AND Treatment. Their related MESH and MTREE keywords were also used. References of the selected articles were also reviewed.

1277 articles were initially identified. After omitting duplicate papers, a thorough review was performed on their abstracts, and a total of 14 relevant articles were selected. The exclusion criteria were: articles regarding the pathophysiology of the Varicella zoster, scars of other etiology, Histologic studies, Herpes zoster scar, animal studies, reviews, communications and articles not written in English. Figure 1 illustrates the Prisma diagram.

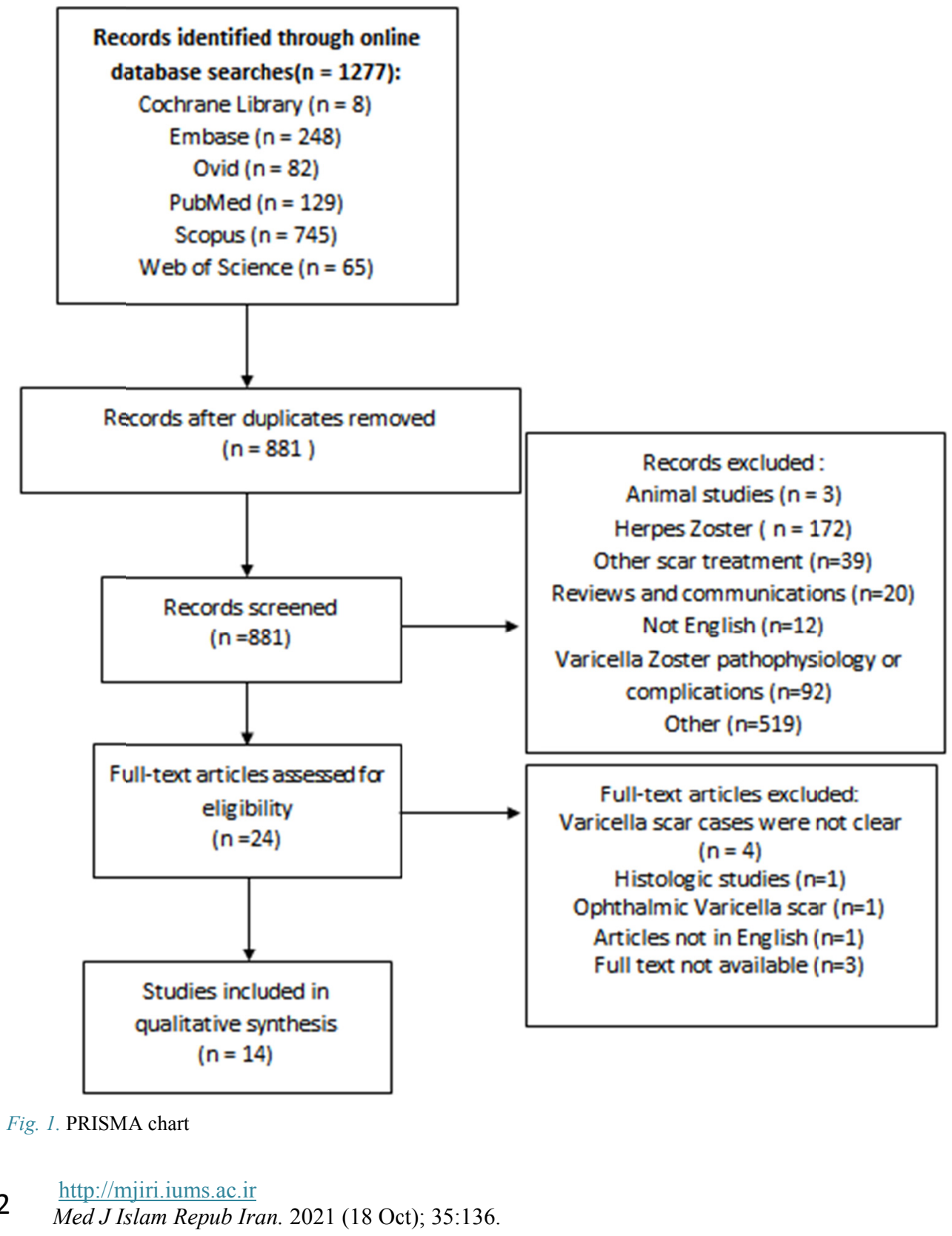




\section{Results}

From the 14 included studies, 11 studies discriminated the PVS cases from other depressed scars, and the final improvement was reported separately as well. From these 11 studies, 5 of them provided only qualitative results and the remaining 6 reported the improvement rates in terms of percentage. Totally 161 PVS cases were identified, of which a majority of 113 cases underwent chemical peeling with TCA. Other trials comprised few PVS cases. Table 1 summarizes the characteristics of the studies.

\section{Medical treatments}

\subsection{Topical}

Several topical agents are being used for scar improvements, such as topical silicone gel sheeting, topical imiquimod, and topical tacrolimus and tretinoin cream.

Tretinoin cream is a recognized peeling agent used in the treatment of many skin defects which promote epidermal hyperplasia and extracellular matrix synthesis including dermal collagen synthesis (10). No exclusive study on its monotherapy effect on PVS was performed, but the tretinoin cream $0.05 \%$ was used in scar site preparation for Er:YAG laser and applied nightly for an average of 3 weeks prior to laser therapy sessions $(11,12)$.

\subsection{Systemic}

1.2.1. Isotretinoin: In Dharmendra et al. study, 3 patients (skin types III-IV) with multiple pigmented facial PVS were treated with oral isotretinoin; dosed $20 \mathrm{mg}$ for two females and $10 \mathrm{mg}$ for one male. Drugs had to be taken every other night for a duration of 1 to 4 months. In the follow-up visits, all the patients had moderate to excellent responses (13).

1.2.2. Topiramate: In one clinical trial, Rakesh et al. treated 91 patients suffering from various scars with oral topiramate $25 \mathrm{mg}$ daily, among which 6 patients had scars due to varicella. An excellent response (more than 75\% improvement) was reported in all cases with PVS within the third month of treatment. PVS showed the greatest improvement among other scars to oral topiramate, followed by acne scars with good to excellent results for $93 \%$ of cases (14).

\section{Noninvasive procedures}

2.1. Chemical Peelings: Chemical peeling is the process of applying chemicals to the skin to destroy the damaged outer layers, allowing the skin to recreate itself (15, 16). These agents have different depths of penetration and are categorized depending on their histological level of necrosis (17). Many types of chemicals have been used to treat atrophic scars, especially acne scars, including Glycolic acid, Trichloroacetic acid (TCA), Jessner's solution, Pyruvic acid, and Salicylic acid (15). Among these only TCA has been employed to treat PVS using a technique called CROSS. However, there is insufficient literature on the efficacy of other agents for this specific scar.

Introduced by Lee et al., chemical reconstruction of skin scars (CROSS) is a technique for treating atrophic scars, delivering high concentration TCA to the deep dermis via a wooden applicator $(18,19)$.
This procedure results in a higher increase in dermal and epidermal thickness as well as more collagen deposition comparing to that of simple TCA application (20).

In one study, 100 patients with PVS (86 women, 14 men; mean age 23 years; Fitzpatrick skin types II-IV) were treated with $70 \%$ TCA utilizing the CROSS technique for a maximum of six sessions at three weeks intervals.

$29 \%$ of the patients had marked improvements before the sixth session and discontinued treatment; the rest $71 \%$ completed all six sittings. The final assessment at $12-$ week showed $41 \%$ marked improvement, $42 \%$ moderate improvement, and $12 \%$ mild improvement (evaluated as quartile percentage by two dermatologists). No case of a worsening scar was seen, and 5 patients showed no improvement. Lastly, 69\% were satisfied with the results.

Adverse events occurred in 34 patients. Mild erythema was seen in 17 patients $(17 \%)$ and faded over 2 weeks using mild topical steroids. Hypopigmentation occurred in $2 \%$ of patients and resolved in 6 to 8 weeks with an overnight application of topical tretinoin $0.05 \%$. Hyperpigmentation was seen in $15 \%$ of cases and disappeared within four weeks after nightly use of topical hydroquinone $4 \%$ on the hyperpigmented area, along with sunscreen (6).

In another study by Agarwal et al., 16 patients (age range: 10-45 years ; Fitzpatrick skin types III-IV) with PVS were treated with 100\% TCA using the CROSS technique; out of which 3 were lost to follow-ups. A total of 4 sessions were given every two weeks, and the results were evaluated after 3 months of the initial therapy.

All of the 13 patients who completed the study showed considerable clinical improvements, with $69 \%$ of patients grading the response as excellent $(>75 \%)$ improvement, whereas the rest $31 \%$, reporting good $(51-75 \%)$ improvement. There was an improvement in associated hyperpigmentation in all of the cases. No significant complication was reported in any patient (21).

In neither of the former studlies, the efficacy of therapy was significantly influenced by the patient's age, skin type, sex, or the duration of scars.

2.2. Microdermabrasion: Despite the wide usage of Microdermabrasion (MDA) in the treatment of different atrophic scars, no individual study was performed to evaluate MDA's efficacy as monotherapy in PVS treatment (22).

2.3. Microneedling: Skin micro-needling accelerates the process of skin regeneration through the creation of several micro-injuries, which emerge when skin is deeply punctured with very thin needles $(23,24)$.

In a case report, a 15-year-old girl with a history of varicella at the age of 3 underwent 3 sessions of microneedling with a monthly interval. She had skin type $\mathrm{V}$ and presented with multiple round atrophic scars on the cheek and forehead.

The operating device consisted of $1.5 \mathrm{~mm}$-long needles. Almost ten passes in horizontal, vertical, and oblique directions were performed in each scarred area.

She had significant improvement in the varicella scars. 


\begin{tabular}{|c|c|c|c|c|c|c|c|c|c|c|}
\hline $\begin{array}{l}\text { First } \\
\text { author, } \\
\text { year }\end{array}$ & $\begin{array}{l}\text { No. PVS } \\
\text { patients/ } \\
\text { No. All } \\
\text { patients }\end{array}$ & $\begin{array}{l}\text { Female } \\
\text { / Male }\end{array}$ & $\begin{array}{l}\text { Mean } \\
\text { Age }\end{array}$ & $\begin{array}{l}\text { Fitzpatrick } \\
\text { skin photo- } \\
\text { type }\end{array}$ & Drug / Modality & Dose / Sessions & $\begin{array}{l}\text { Follow up } \\
\text { period }\end{array}$ & Result & Adverse effects & $\begin{array}{c}\text { Study } \\
\text { limitations }\end{array}$ \\
\hline $\begin{array}{l}\text { Dave, } \\
2019\end{array}$ & $3 / 3$ & $2 / 1$ & - & $\begin{array}{l}\text { III-IV } \\
\end{array}$ & Oral Isotretinoin & $\begin{array}{l}10-20 \mathrm{mg} \text { on Alternate days for } \\
1-4 \text { month }\end{array}$ & $3 y-9 m-3 m$ & $\begin{array}{l}\text { Moderate to excellent Im- } \\
\text { provement }\end{array}$ & - & $\begin{array}{l}\text { Qualitative } \\
\text { Results }\end{array}$ \\
\hline $\begin{array}{l}\text { Agarwal, } \\
2013\end{array}$ & $13 / 13$ & $8 / 5$ & $10-45$ & III-IV & $\begin{array}{c}100 \% \text { TCA - CROSS } \\
\text { technique }\end{array}$ & 4 sessions - every 2 weeks & $3 \mathrm{~m}$ & $\begin{array}{l}69 \% \text { excellent improvement } \\
(>75 \%), 31 \% \text { good improve- } \\
\text { ment }(51-75 \%)\end{array}$ & $\begin{array}{l}\text { Transient erythema in all } \\
\text { patients }\end{array}$ & - \\
\hline $\begin{array}{l}\text { Barikbin, } \\
2012\end{array}$ & $100 / 100$ & $86 / 14$ & 23 & II-IV & $\begin{array}{l}\text { 70\% TCA - CROSS } \\
\text { technique }\end{array}$ & Up to 6 sessions every 3 weeks & $12 \mathrm{w}$ & $\begin{array}{c}41 \% \text { marked improvement } \\
(>75 \%), 42 \% \text { moderate im- } \\
\text { provement }(50-75 \%), 12 \% \\
\text { mild improvement }(25-50 \%) \\
5 \% \text { no improvement }\end{array}$ & $\begin{array}{c}\text { Mild erythema in } 17 \%, \\
\text { Hypopigmentation in } 2 \%, \\
\text { Hyperpigmentation in } \\
15 \%\end{array}$ & - \\
\hline Lee, 2013 & $3 / 3$ & $2 / 1$ & 24.3 & - & $\begin{array}{l}\text { Intradermal incision \& } \\
\text { Er:YAG laser }\end{array}$ & $\begin{array}{c}\text { One intracision session and } \\
\text { after one month a 2940-nm } \\
\text { Er:YAG laser }\end{array}$ & $1 \mathrm{~m}$ & $\begin{array}{l}\text { Great,significant,marked im- } \\
\text { provements }\end{array}$ & - & $\begin{array}{l}\text { Qualitative } \\
\text { results }\end{array}$ \\
\hline $\begin{array}{l}\text { Badawi, } \\
2011\end{array}$ & $15 / 15$ & $0 / 15$ & 42 & IV-V & $\begin{array}{l}\text { Microdermabrasion } \\
\text { therapy, followed by } \\
\text { 1064-nm Nd:YAG laser }\end{array}$ & $\begin{array}{c}\text { Microdermabrasion every } 7 \text { to } \\
10 \text { days for } 8 \text { sessions and laser } \\
\text { treatments every } 3 \text { to } 4 \text { weeks } \\
\text { for } 5 \text { to } 6 \text { sessions, with } 3 \text { days } \\
\text { interval }\end{array}$ & $9 \mathrm{~m}$ & $\begin{array}{l}\text { Mean improvement score } 1.9 \\
\text { (scale: } 2=\text { marked improve- } \\
\text { ment; } 1=\text { mild improvement) }\end{array}$ & $\begin{array}{c}\text { Transient edema and } \\
\text { erythema in some patients }\end{array}$ & $\begin{array}{l}\text { Percentile } \\
\text { improvement } \\
\text { was not } \\
\text { reported }\end{array}$ \\
\hline $\begin{array}{l}\text { Kavoussi, } \\
2019\end{array}$ & $1 / 1$ & $1 / 0$ & 28 & - & $\begin{array}{l}\text { Punch elevation, autolo- } \\
\text { gous fat injection and } \\
\text { fractional CO2 laser }\end{array}$ & All in single session & $2 y$ & $\begin{array}{c}\text { Significant improvement / } \\
\text { mild-to-moderate improvement } \\
\text { of the previous post- } \\
\text { inflammatory hyperpigmenta- } \\
\text { tion }\end{array}$ & - & $\begin{array}{l}\text { Qualitative } \\
\text { Result }\end{array}$ \\
\hline $\begin{array}{l}\text { Costa, } \\
2014\end{array}$ & $1 / 1$ & $1 / 0$ & 15 & $\mathrm{~V}$ & Microneedling & 3 Sessions - 1 month interval & $16 \mathrm{~m}$ & Significant improvement & Transient erythema & $\begin{array}{l}\text { Qualitative } \\
\text { Results }\end{array}$ \\
\hline $\begin{array}{l}\text { Shilpa, } \\
2016\end{array}$ & $2 / 15$ & $8 / 7$ & 35 & - & Dermal Grafting & $\begin{array}{l}\text { Dermabraison prior to surgery- } \\
\text { Single session }\end{array}$ & $6 \mathrm{~m}$ & Significant improvement & $\begin{array}{l}\text { Transient edema and } \\
\text { bruise in some patients }\end{array}$ & $\begin{array}{l}\text { Qualitative } \\
\text { results }\end{array}$ \\
\hline $\begin{array}{l}\text { Rakesh, } \\
2005\end{array}$ & $6 / 91$ & $51 / 40$ & - & - & Oral Topiramate & $25 \mathrm{mg}$ daily for 1 month & $3 \mathrm{~m}$ & $\begin{array}{c}\text { Excellent Improvement } \\
(>75 \%)\end{array}$ & - & - \\
\hline
\end{tabular}




\begin{tabular}{|c|c|c|c|c|c|c|c|c|c|c|}
\hline $\begin{array}{l}\text { First au- } \\
\text { thor, year }\end{array}$ & $\begin{array}{l}\text { No. PVS } \\
\text { patients/ } \\
\text { No. All } \\
\text { patients } \\
\end{array}$ & $\begin{array}{l}\text { Female } \\
\text { / Male }\end{array}$ & $\begin{array}{l}\text { Mean } \\
\text { Age }\end{array}$ & $\begin{array}{l}\text { Fitzpatrick } \\
\text { skin photo- } \\
\text { type }\end{array}$ & Drug / Modality & Dose / Sessions & $\begin{array}{l}\text { Follow up } \\
\text { period }\end{array}$ & Result & Adverse effects & $\begin{array}{c}\text { Study } \\
\text { limitations }\end{array}$ \\
\hline $\begin{array}{l}\text { Aalami } \\
\text { Harandi, } \\
2011\end{array}$ & $6 / 58$ & $34 / 24$ & 28.7 & $\begin{array}{l}\text { III-IV } \\
\end{array}$ & $\begin{array}{l}\text { Subcision, and } \\
\text { subsequent suction- } \\
\text { ing }\end{array}$ & $\begin{array}{c}\text { subcision, using } \\
\text { lancing and fanning } \\
\text { motions, and subse- } \\
\text { quent suctioning } \\
\text { after three days and } \\
\text { repeating it at least } \\
\text { every other day for } 2 \\
\text { weeks. }\end{array}$ & $6 \mathrm{~m}$ & $\begin{array}{c}71.73 \% \\
\text { (46p:Completedprotocol) } \\
43.75 \text { (12p:Late Suctioning) }\end{array}$ & $\begin{array}{l}\text { Transient edema and discoloration } \\
\text { which diminished in 1-2 weeks / } \\
\text { hemorrhagic papules in some pa- } \\
\text { tients which drained with a needle/ }\end{array}$ & $\begin{array}{c}\text { The im- } \\
\text { provement of } \\
\text { varicella } \\
\text { scars were } \\
\text { not exclu- } \\
\text { sively re- } \\
\text { ported }\end{array}$ \\
\hline Kye, 1997 & $5 / 30$ & $4 / 1$ & 25.4 & III-IV & Er:YAG & Single session & $3 \mathrm{~m}$ & $\begin{array}{c}3 \text { patients with PVS or small } \\
\text { pox scars improved } 25-50 \%, \\
\text { five patients improved } 50-75 \% \text {, } \\
\text { and one patient improved more } \\
\text { than } 75 \% \text { (Overall improve- } \\
\text { ment } 55 \%)\end{array}$ & Transient erythema & $\begin{array}{l}\text { PVS and } \\
\text { small pox } \\
\text { scar were } \\
\text { reported } \\
\text { together }\end{array}$ \\
\hline $\begin{array}{l}\text { Bernstein, } \\
1998\end{array}$ & $1 / 30$ & $22 / 8$ & 54.3 & - & $\begin{array}{l}\text { Short-pulsed } \mathrm{CO}_{2} \\
\text { laser or continued } \\
\text { wave-length } \mathrm{CO}_{2}\end{array}$ & Single session & $2 \mathrm{~m}$ & $>50 \%$ improvement & Transient erythema & - \\
\hline $\begin{array}{l}\text { Cho SI, } \\
199\end{array}$ & $4 / 158$ & $138 / 20$ & 39.9 & IV-V & $\begin{array}{c}\mathrm{CO}_{2} \text { laser and sub- } \\
\text { sequent Er:YAG } \\
\text { laser }\end{array}$ & Single session & $3 \mathrm{~m}$ & $\begin{array}{c}2 \text { patients: } 70-79 \% \text { improve- } \\
\text { ment } \\
\begin{array}{c}2 \text { patients: } 80-89 \% \text { improve- } \\
\text { ment }\end{array}\end{array}$ & $\begin{array}{l}\text { Transient erythema in all subjects / } \\
\text { hypertrophic scars in } 18.5 \% \text { of the } \\
\text { patients }(n=29)\end{array}$ & - \\
\hline Goh, 2002 & $1 / 16$ & 9/7 & 30.7 & III-IV & Uni pulse $\mathrm{CO}_{2}$ laser & Single session & $3-12 \mathrm{~m}$ & $\begin{array}{l}\text { moderate to excellent im- } \\
\text { provement }(25 \%-75 \%)\end{array}$ & $\begin{array}{l}\text { Transient erythema/ Hypopigmen- } \\
\text { tation in one patient/ Hyperpigmen- } \\
\text { tation in one patient }\end{array}$ & $\begin{array}{l}\text { Improve- } \\
\text { ment of } \\
\text { varicella scar } \\
\text { was not } \\
\text { exclusively } \\
\text { reported }\end{array}$ \\
\hline
\end{tabular}


The only adverse effect was transient erythema which faded away in the first week, and no other complications were reported during the 16-month follow-up (24).

2.4. Lasers

2.4.1. $\mathrm{CO}_{2}$ Laser: Carbon dioxide $\left(\mathrm{CO}_{2}\right)$ laser is an effective and mostly a choice treatment for atrophic scars. Having a wavelength of $10,600 \mathrm{~nm}$, it is absorbed by the water in intracellular tissues and can selectively heat and vaporize superficial skin layers (23). Through controlled heating of dermal collagen fibers, the traditional $\mathrm{CO}_{2}$ laser can destroy the fragmented collagen matrix, promoting new collagen formation and subsequent scar appearance improvement $(25,26)$.

In one study by Bernstein et al., 30 patients (aging between 14 and 84 years), with various types of scars were treated by a single laser session utilizing either a highenergy, short-pulsed $\mathrm{CO}_{2}$ laser (energy:300 mJ and $60 \mathrm{~W}$, density pattern $=6)(\mathrm{n}=13)$ or a continuous wave $\mathrm{CO}_{2}$ laser with a flash-scanning attachment $(20 \mathrm{~W}$, pulse duration $=0.2$ seconds, spot size $=6-\mathrm{mm})(\mathrm{n}=17)$. Out of 30 patients, four of them had scars due to varicella or acne consisting of three acne cases and one PVS.

Final evaluation was made by four independent health workers at second-month follow-up, reporting more than $50 \%$ improvement in all acne/varicella scars. The only adverse event was erythema which persisted from 7 to 24 weeks varying on the depth of laser resurfacing (27).

In another study on 30 patients with skin type III and IV from which only one patient had chickenpox scar; Unipulse $\mathrm{CO}_{2}$ laser resurfacing system was used. The power at tissue was set at 15 watts (fluency $=6.12 \mathrm{~J} / \mathrm{cm}^{2}$; spot size $=1.02 \mathrm{~mm}$, frequency $=300 \mathrm{~Hz}$ ), with a $20 \%$ overlap. The final result at six months was moderate to excellent improvement (25\%-75\%) in more than $60 \%$ of cases.

The major complication was severe erythema on the first day in all patients. By three months, only $22 \%$ of patients had minimal erythema and by six months, none of them had erythema (28).

2.4.2. Er:YAG: The pulsed Er:YAG laser is proven to be an effective treatment for many kinds of pitted scars. The Er:YAG laser has a 2936-nm wavelength and with a skin penetration to a depth of $5 \mu \mathrm{m} /$ pulse for $2.8 \mathrm{~J} / \mathrm{cm}^{2}$, being strongly absorbed by water $(29,30)$.

In a study of 21 patients with atrophic facial scars (skin type III-IV, mean age 25.4 years, 16 females, 5 males), 5 cases had PVS , and 4 patients had scars due to smallpox.

Skin resurfacing with a pulsed Er:YAG laser was done. The systems settings were $500 \mathrm{~mJ} /$ pulse, $3.5-4.5 \mathrm{~W}$, pulse frequencies of 7-9 Hz, with the use of a $2 \mathrm{~mm}$ sized handpiece. Up to six passes were performed and the operation was stopped when a pinpoint appeared on the scars' margin.

Three months after laser treatment, 3 patients with PVS or smallpox scars improved $25-50 \%$, five patients improved $50-75 \%$, and one patient improved more than $75 \%$ (55\% improvement on average).

Major complications included erythema on laserirradiated sites that disappeared in all patients after 3 months. Also, minimal post-inflammatory hyperpigmentation was observed only in two patients (11).
In an attempt to determine the efficacy of combined treatment of atrophic facial scars with high-energy pulsed $\mathrm{CO}_{2}$ laser and Er:YAG laser, Cho and Kim treated 158 patients with both modalities. All subjects had skin types IV or $\mathrm{V}$ and ranged in age from 21 to 65 years (mean 39.9 years). Four patients were known cases of PVS.

Laser therapy was a two-step procedure. First, using the $\mathrm{CO}_{2}$ laser, up to three passes were performed on the cosmetic units or full face (energy 250-300 mJ (50-60 W), pattern 3 (square), size 9, density 4-6); Then, using the Er: YAG laser, the scars were featheredged $(2940 \mathrm{~nm}$ wavelength, energy $200-1000 \mathrm{~mJ}$, repetition rate 5-10 $\mathrm{Hz})$.

An evaluation in 10.6 months on average from the initial treatment revealed $70-90 \%$ improvement in patients with PVS.

All of the subjects developed transient postoperative erythema, which faded away after 84 days on average. Also, transient-2-week edema and pruritus were developed in all patients. Noticeably, hypertrophic scars occurred in $18.5 \%$ of the patients $(n=29)$, and in $4.4 \%$ of the patients $(n=7)$, it lasted for more than 3 months (12).

\section{Invasive Procedures}

3.1. Subcision-suction: Subcision (subcutaneous incision-less surgery) is a surgical intervention used to treat a variety of depressed skin scars $(31,32)$. Subcision improves the scars by releasing fibrotic strands beneath scars, recruitment of blood in the induced dermal pocket, and initiating connective tissue formation (33). The downside to this technique is the high recurrence rate, especially 2-5 days from the procedure until the 17th day. To overcome this challenge, Aalami Harandi et al. suggested repeated suctioning during this period. They treated 58 patients ( 34 females and 24 males, mean age: 28.68 years, skin types III-IV) with dlepressed scars, including 6 cases of PVS. The treatment protocol was subcision using lancing and fanning motions, and subsequent suctioning after three days and repeating it at least every other day for 2 weeks. Subcision was applied using a $23 \mathrm{G}$ needle or Nokor $18 \mathrm{G}$ needle for very fibrotic scars. Suctioning was done by a handpiece of a microdermabrasion device (without crystal abrasion, with a $5 \mathrm{~mm}$ disposable nozzle).

Sixth-month evaluation by two investigators revealed $71.73 \%$ mean improvement in the patients who submitted the suctioning protocol completely; and $43.75 \%$ in the group that started suctioning with more than five days delay. Patients' view scores were $75.43 \%$ and $49.16 \%$, respectively. Improvement was greater by up to $5 \%$ in the group that had more frequent suctioning in the first week than the advised protocol.

Adverse events included transient edema and discoloration that diminished in 2 weeks and some developed hemorrhagic papules, which were drained with a needle. No hyperpigmentation was observed in any patient (34).

3.2. Dermal grafting: Dermal grafting is the implantation of the appropriately dissected deep dermis into corresponding recipient areas such as atrophic scars or other soft tissue defects (35).

Shilpa et al. evaluated dermal grafting in the treatment 
of 15 atrophic facial scar cases, from which two were PVS.

All patients received a single subcision session two weeks prior to the planned surgery, and the retro-auricular area was chosen as the donor area.

Dermabrasion using dental burrs was performed in the donor site to remove the entire epithelium enhancing the graft outcome. Dermal grafts were harvested as linear strips or by using a $6 \mathrm{~mm}$ punch, depending on the scar type. In the recipient area, for circular or irregular scars, grafts were placed below them using a pocket technique, in which a pocket was created below the scar by doing subcision using an 18-G needle. The prepared grafts were then inserted into the pocket, and tissue insertion was repeated if necessary. Patients were followed up again after six months, and results were assessed using a VAS (visual analogue scale) ranging from 1 (least satisfied) to 10 (most satisfied). 13 patients were scored above 7 and all of them were more than $50 \%$ satisfied. Acne, varicella and traumatic scars improved significantly (36).

\section{Combination therapy}

4.1. Intradermal incision with Er:YAG laser: Intracision is a modified form of subcision. In intracision, the mechanisms of scar improvement are as follows: untethering fibrotic strands, enhancing blood pool formation in the dermal pockets and raising collagen synthesis by the focal dermal wound-healing response.

In a case report of three PVS patients, Lee et al. used an intradermal incision in combination with Er:YAG laser and evaluated scars after one month. Their method included one intracision session (with 18-gauge Nokor needle) following a 2940-nm Er:YAG (20 or $40 \mathrm{~mJ} / \mathrm{cm} 2$ ) laser treatment with a one-month interval. The final evaluation revealed marked improvement in all three patients. No permanent adverse effect was noted (37).

4.2. Microdermabrasion and Nd:YAG: In one retrospective study; Badawi et al. evaluated the efficacy of a non-ablative, sub-millisecond, 1064nm Nd:YAG laser in combination with microdermabrasion (MDA) therapy over 6 months to treat facial chickenpox scarring in 15 males with Fitzpatrick skin types IV or V. Participants were treated at a fluency of 14 to $16 \mathrm{~J} / \mathrm{cm} 2$ and a pulse duration of 0.4 milliseconds with a repetition rate of $5 \mathrm{~Hz}$. Each participant underwent 5 to 6 sessions of laser treatments every 3 to 4 weeks; also, 8 MDA sessions were performed 7 to 10 days apart. The mean follow-up time was 9.1 months. Final evaluation was made by both participants and treating physicians with scoring as follows: $2=$ marked improvement; $1=$ mild improvement

Results of the participant assessment revealed marked improvement with mean scores in scarring, skin texture, and post-inflammatory hyperpigmentation (PIH) of 1.8, 1.9 , and 1.8, respectively. The results of the blinded photographic assessments indicated clinically significant improvements in scarring, skin texture, and $\mathrm{PIH}$, with mean scores of 1.9, 1.8, and 1.8, respectively (38).

4.3. Punch elevation, autologous fat injection, and fractional $\mathrm{CO}_{2}$ laser: In Another case report, a 28-year-old woman with a refractory PVS underwent sequential treatment with punch elevation, autologous fat injection, and fractional $\mathrm{CO}_{2}$ laser (Density 6\%, Energy $30 \mathrm{~mJ}$, Fluence $13.5 \mathrm{~J} / \mathrm{cm}^{2}$ ), all in a single session. Assessment in two years revealed significant improvement of scar and also patient satisfaction. The sicar's previous PIH showed only mild to moderate improvement to treatment (39).

\section{Discussion}

Atrophic scars like PVS are very challenging to treat. Therefore many techniques have been suggested to enhance the efficacy of treatment (15). Most studies do not discriminate between different atrophic scars, but this study especially focused on PVS treatment due to its prevalence and cosmetic impact. Evidently, the most promising result was seen in two trials utilizing chemical peeling with CROSS technique revealing a marked improvement in the majority of cases (6). The improvement was amplified with higher concentrations of TCA (21). Surgical techniques like subcision-suction were also favorable with up to $75 \%$ improvement (34). Despite the widespread use of lasers in scar removal procedures, their evidence was limited on PVS. The $\mathrm{CO}_{2}$ and Er:YAG lasers were effective, revealing $25 \%$ to $50 \%$ improvement. Their efficacy was increased when a combination of these two lasers was used $(11,12)$. Combination therapies including intradermal incision with Er:YAG and also, Microdermabrasion with $\mathrm{Nd}$ :YAG laser, were also effective, resulting in marked improvements $(37,38)$. In systemic medical treatments, the off-label use of topiramate and isotretinoin revealed marked improvements, but they are used limitedly in practice $(13,14)$.

Adverse effects were minimal in most studies. Transient erythema was most commonly reported in almost every procedure. Hypo and hyperpigmentations were only reported in TCA application which faded away using topical keratolytic creams. Hypertrophic scars were only reported in subcision-suction method $(1.7 \%)$ and laser combination therapy with $\mathrm{CO}_{2}$ and Er:YAG (18.5\%). It could be concluded that the adverse effects of the used methods were transient and not of significance.

The major drawback to this review is the few trials that failed to report the PVS improvement rates separately, and the final results were reported together with other depressed scars. Based on the findings, the current methods used in the treatment of PVS have various but satisfactory results. Therefore it could be assumed that PVS demonstrate a moderate response to treatment. However, the authors suggest comparative studies comprising larger study groups with a specific focus on PVS to improve the quality of assessment in the future.

In clinical practice, several other methods and modalities are being used in the treatment of PVS including Dermabraison, Punch elevation, subdermal normal saline injection, fractional micro-needling, RF, scar revision surgery and etc. But due to their absence in publications, they were not mentioned in this article.

While selecting the proper choice for PVS treatment, two factors should be considered; the scar characteristics: scar's depth, size, pigmentation, and secondly, patient's skin features as its skin type, keloid formation vulnerabil- 
ity, and history of post-inflammatory hyperpigmentations.

\section{Conclusion}

In general, TCA treatment with the CROSS technique was the most frequently used method, demonstrating moderate to excellent improvement in the majority of the cases. Most studies in this field comprised few PVS cases. Therefore further studies with larger populations are required to properly compare the efficacy of each modality. Experts suggest combination therapy in order to maximize the efficacy of treatment and achieving higher patients' satisfaction.

\section{Conflict of Interests}

The authors declare that they have no competing interests.

\section{References}

1. Amela Heras C, Pena-Rey I, Pachon del Amo I, Martinez de Aragon MV. [Update on chickenpox]. Rev Clin Esp. 2006;206(1):48-9.

2. Leung AK, Kao CP, Sauve RS. Scarring resulting from chickenpox. Pediatr Dermatol. 2001;18(5):378-80.

3. Jezek Z, Hardjotanojo W, Rangaraj AG. Facial scarring after varicella. A comparison with variola major and variola minor. Am J Epidemiol. 1981;114(6):798-803.

4. Brown BC, McKenna SP, Siddhi K, McGrouther DA, Bayat A. The hidden cost of skin scars: quality of life after skin scarring. J. Plast. Reconstr Aesthet Surg. 2008;61(9):1049-58.

5. Konda S, Potter K, Ren VZ, Wang AL, Srinivasan A, Chilukuri S. Techniques for optimizing surgical scars, part 1 : Wound healing and depressed/atrophic scars. SKINmed. 2017;15(4):271-6.

6. Barikbin B, Saadat N, Akbari Z, Yousefi M, Toossi P. Focal highconcentration trichloroacetic acid peeling for treatment of atrophic facial chickenpox scar: An open-label study. Dermatol Surg. 2012;38(10):1662-7.

7. Requena L, Requena C. Histopathology of the More Common Viral Skin Infections. Actas Dermosifiliogr. 2010;101(3):201-16.

8. Behrangi E, Goodarzi A, Roohaninasab M, Sadeghzadeh-Bazargan A, Nobari NN, Ghassemi M. A review of scar treatment related to acne and burn. J Crit Rev. 2020;7(4):714-22.

9. Goodarzi A, Behrangi E, Ghassemi M, Nobari NN, SadeghzadehBazargan A, Roohaninasab M. Acne scar; a review of classification and treatment. J Crit Rev. 2020;7(7):1108-14.

10. Bolognia J, Schaffer JV, Cerroni L. Dermatology. two2018. p. 2204.

11. Kye YC. Resurfacing of pitted facial scars with a pulsed Er:YAG laser. Dermatol Surg. 1997;23(10):880-3.

12. Cho SI, Kim YC. Treatment of atrophic facial scars with combined use of high-energy pulsed $\mathrm{CO}_{2}$ laser and Er:YAG laser: a practical guide of the laser techniques for the Er: YAG laser. Dermatol Surg. 1999;25(12):959-64.

13. Dave DD, Abdelmaksoud A. Low dose isotretinoin for pigmented post-varicella scars. Dermatol. Ther. 2019;32(1).

14. Rakesh B, Lovedhi A. Topiramate and scars. Dermatol Online J. 2005;11(3)

15. Gozali MV, Zhou B. Effective treatments of atrophic acne scars. J Clin Aesthet Dermatol. 2015;8(5):33-40.

16. Clark E, Scerri L. Superficial and medium-depth chemical peels. Clin Dermatol. 2008;26(2):209-18.

17. Monheit GD. Chemical peels. Skin Therapy Lett. 2004;9(2):6-11.

18. Lee JB, Chung WG, Kwahck H, Lee KH. Focal treatment of acne scars with trichloroacetic acid: chemical reconstruction of skin scars method. Dermatol Surg. 2002;28(11):1017-21; discussion 21.

19. Fabbrocini G, Cacciapuoti S, Fardella N, Pastore F, Monfrecola G. CROSS technique: Chemical reconstruction of skin scars method. Dermatol Ther. 2008;21(SUPPL. 3):S29-S32.

20. Cho SB, Park CO, Chung WG, Lee KH, Lee JB, Chung KY. Histometric and histochemical analysis of the effect of trichloroacetic acid concentration in the chemical reconstruction of skin scars method. Dermatol Surg. 2006;32(10):1231-6; discussion 6.

21. Agarwal N, Mittal A, Kuldeep C, Gupta LK, Khare AK, Mehta S.
Chemical reconstruction of skin scars therapy using $100 \%$ trichloroacetic Acid in the treatment of atrophic facial post varicella scars: a pilot study. J Cutan Aesthet Surg. 2013;6(3):144-7.

22. Badawi A, Soliman M, Sobhi R, Fawzy S, Shokeir H, Salem AM. Microdermabrasion in cosmetic dermatology: A clinical study. Cosmet Dermatol. 2006;19(3):191-6.

23. Sobanko JF, Alster TS. Management of acne scarring, part I: a comparative review of laser surgicall approaches. Am J Clin Dermatol. 2012;13(5):319-30

24. Costa IM, Costa MC. Microneedling for varicella scars in a darkskinned teenager. Dermatol Ther. 2014;40(3):333-4.

25. Orringer JS, Kang S, Johnson TM, Karimipour DJ, Hamilton T, Hammerberg $\mathrm{C}$, et al. Connective tissue remodeling induced by carbon dioxide laser resurfacing of photodamaged human skin. Arch Dermatol. 2004;140(11):1326-32.

26. Golnaz M, Mahrokh F, Azadeh Gi, Siamak Farokh F, Masoomeh R, Mohammadreza G, et al. Comparison of the therapeutic effect of microneedling with carbon dioxide laser in hypertrophic burn scars: a randomized clinical trial. Iran J Dermatol. 2019;22(2):53-7.

27. Bernstein LJ, Kauvar ANB, Grossman MC, Geronemus RG. Scar resurfacing with high-energy, short-pulsed and flashscanning carbon dioxide lasers. Dermatol Surg. 1998;24(1):101-7.

28. Goh CL, Khoo L. Laser skin resurfacing treatment outcome of facial scars and wrinkles in Asians with skin type III/IV with the Unipulse $\mathrm{CO}_{2}$ laser system. Singapore Med J. 2002;43(1):28-32.

29. Kaufmann R, Hibst R. Pulsed Er:YAG- and 308 nm UV-excimer laser: an in vitro and in vivo study of skin-ablative effects. Lasers Surg Med. 1989;9(2):132-40.

30. Walsh JT Jr, Deutsch TF. Er: YAG laser ablation of tissue: measurement of ablation rates. Lasers Surg Med. 1989;9(4):327-37.

31. Goodman GJ. Therapeutic undermining of scars (Subcision). Australas J Dermatol. 2001;42(2):114-7.

32. Orentreich DS, Orentreich N. Subcutaneous incisionless (subcision) surgery for the correction of depressed scars and wrinkles. Dermatol Surg. 1995;21(6):543-9.

33. Alam M, Omura N, Kaminer MS. Subcision for acne scarring: technique and outcomes in 40 patients. Dermatol Surg. 2005;31(3):310-7; discussion 7

34. Aalami Harandi S, Balighi K, Lajevardi V, Akbari E. Subcisionsuction method: A new successful combination therapy in treatment of atrophic acne scars and other depressed scars. J Eur Acad Dermatol. 2011;25(1):92-9.

35. Klein AW. Tissue Augmentation in Clinical Practice. 2nd ed: Taylor \& Francis; 2005

36. Shilpa K, Sacchidanand S, Leelavathy B, Shilpashree P, Divya G, Ranjitha R, et al. Outcome of Dermal Grafting in the Management of Atrophic Facial Scars. J Cutan Aesthet Surg. 2016;9(4):244-8.

37. Lee SJ, Kim YK, Choi SY, Park KY, Seo SJ. Sequential treatment with intradermal incision (intracision) and 2,940-nm Er:YAG laser for chicken pox scars. Dermatol Ther. 2:014;27(1):24-7.

38. Badawi A, Tome M, Kemeny L, Turely A. Successful treatment of chickenpox scars with microdermabrasion and a non-ablative, submillisecond, 1064nm Nd: YAG. Lasers Surg Med. 2012;44:66-7.

39. Kavoussi R, Kavoussi H. Treatment of varicella skin scars with sequential punch elevation, autologous fat injection and fractional $\mathrm{CO}_{2}$ laser. Iran J Dermatol. 2019;22(4):161-4. 